\title{
Aerial Radiological Measuring Surveys of the Oyster Creek Nuclear Power Plant August 1969
}

\author{
EG\&G, Inc., Las Vegas, Nevada
}

\begin{abstract}
This report is part of a series on the continuing activities of the Aerial Radiological Measuring System operated for the US Atomic Energy Commission The ARMS program is managed by the Division of Operational Safety and is a cooperative effort among various offices and divisions of the Commission
\end{abstract}

\author{
Issuance Date: January 1973
}

Published by the U. S. Atomic Energy Commission Technical Information Center 


\section{DISCLAIMER}

This report was prepared as an account of work sponsored by an agency of the United States Government. Neither the United States Government nor any agency Thereof, nor any of their employees, makes any warranty, express or implied, or assumes any legal liability or responsibility for the accuracy, completeness, or usefulness of any information, apparatus, product, or process disclosed, or represents that its use would not infringe privately owned rights. Reference herein to any specific commercial product, process, or service by trade name, trademark, manufacturer, or otherwise does not necessarily constitute or imply its endorsement, recommendation, or favoring by the United States Government or any agency thereof. The views and opinions of authors expressed herein do not necessarily state or reflect those of the United States Government or any agency thereof. 


\section{DISCLAIMER}

Portions of this document may be illegible in electronic image products. Images are produced from the best available original document. 


\section{CONTENTS}

ABSTRACT .

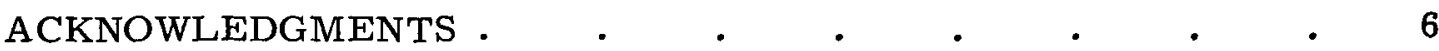

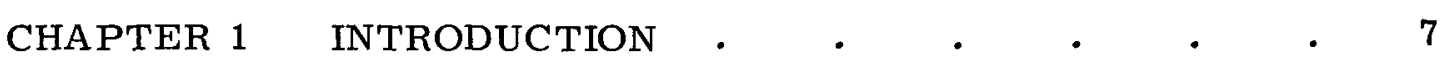

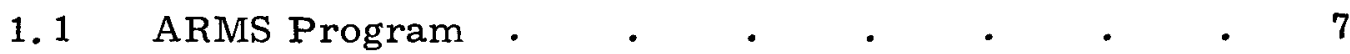

1.2 Oyster Creek Nuclear Power Plant . $\quad$. $\quad$. $\quad$. 7

1.3 ARMS Equipment and Procedures . 3 . $\quad$. $\quad$. 7

1. 4 Reduction and Presentation of Data . . . . 10

$\begin{array}{lllllll}\text { CHAPTER } 2 & \text { PLANNED SURVEY AREA } & \text { • } & \text { • } & \text { • } & \text { - }\end{array}$

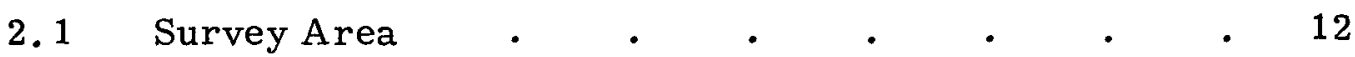

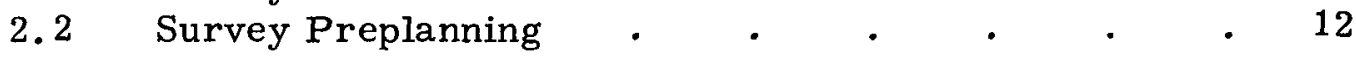

CHAPTER 3 OYSTER CREEK REACTOR AND SITE

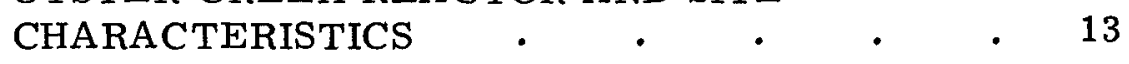

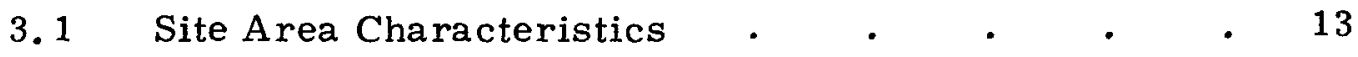

CHAPTER 4 RADIOLOGICAL SURVEY $\quad$ - $\quad$ • $\quad$ • 15

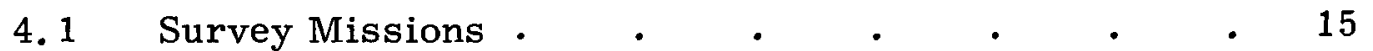

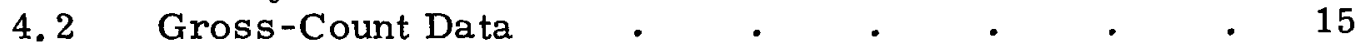

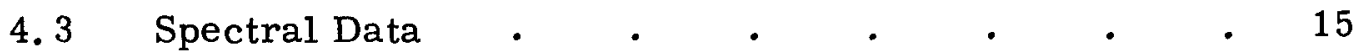

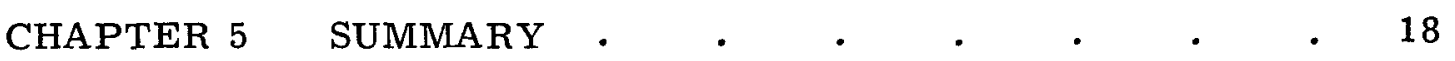

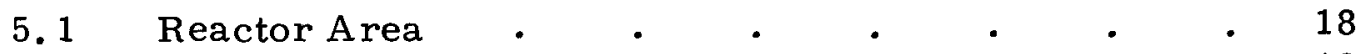

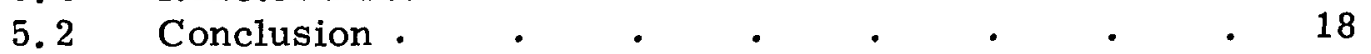

APPENDIX A GAMMA-RAY SPECTRAL CHARTS $\quad \cdot \quad$ - $\quad 19$ 


\section{ABSTRACT}

The Aerial Radiological Measuring System (ARMS) was used to perform an aerial radiological survey of the Oyster Creek Nuclear Power Plant and surrounding area during August 1969.

A high-sensitivity detection system collected gamma-ray spectral and gross-count data. The data were then computer processed into an isoexposure contour map, 3 feet above the ground, of a 240 square mile area. Results indicated the presence of isotopes normally found in the background radiation throughout the United States. 


\section{ACKNOWLEDGMENTS}

Acknowledgment should be given to the ARMS team involved in this survey. They are as follows: Edward D. Shultz (Captain Pilot), Vernon F. Weissman (Navigator), and Robert J. Mazurkewiz (Instrumentation Specialist).

The editors and reviewers of this report were John F. Doyle, Zolin G. Burson, and Philip K. Boyns.

Special appreciation is given to Joe Deal (AEC-Division of Biology \& Medicine) and Dr. Charles A. Pelletier (AEC Regulatory), as well as their associates and correspondents, for their painstaking reviews and comments of the several drafts of this report. 


\section{CHAPTER 1 INTRODUCTION}

\section{1 ARIMS PROGRAM}

The Aerial Radiological Measuring System $(A R M S)^{1}$ operated by EG\&G, Inc., Las Vegas, Nevada for the U. S. Atomic Energy Commission, was used to perform an aerial radiological survey of an extensive area surrounding the Oyster Creek Nuclear Power Plant during August 1969.

This survey was made as part of a continuing nationwide ARMS program started in 1958 to determine radiation levels surrounding facilities maintaining or utilizing radioactive materials. The present survey represents the first such performed in the Oyster Creek Nuclear Power Plant area since the plant began operation in 1969 .

The high-sensitivity detection system on board the aircraft collects gamma-ray spectral and gross-count data on each flight line of the survey. The gamma-radiation and aircraft-position information are documented for processing by a computer into an isoexposure contour of the area surveyed.

\subsection{OYSTER CREEK NUCLEAR POWER PLANT}

The reactor is a boiling water type. The Oyster Creek Reactor, Unit 1, has a thermal power output of 1,930 megawatts and an electrical power output of 650 megawatts. The principal nuclear contractor is the General Electric Company. It is operated by the Jersey Central Power \& Light Company. The reactor was in an initial startup phase at the time of the survey.

\section{3 ARMS EQUIPMENT AND PROCEDURES}

The ARMS aircraft and its on-board radiation detection equipment were used to measure the radiation from the Oyster Creek facility and the surrounding area. The ARMS equipment and procedures have been discussed in detail ${ }^{1}$ and, hence, will only be described briefly here.

The ARMS surveys are flown in a Beechcraft Twin Bonanza at an altitude of 300 to 500 feet above the ground level (AGL) at a ground speed of about 140 knots $(235 \mathrm{ft} / \mathrm{sec})$. A typical flight pattern consists 
of a grid of parallel paths 5 to 25 miles in length with a spacing of $1 / 4$ to 2 miles. The ground position of the aircraft as well as its altitude AGL are measured and recorded every other second via a radarnavigation-computer system. The position and altitude measurements are accurate to \pm 350 and $\pm 5 \mathrm{ft}$, respectively, although greater position accuracy can be inferred.

The aerial radiation measurements are of two distinct types and both are made simultaneously: gross gamma count (intensity) measurements and gamma spectral (identity) measurements. The detector system, common to both, consists of an integrated package of fourteen 4 - by 4-in. NaI(Tl) scintillation crystals, each mounted on its own photomultiplier assembly. The detector system output is directed both to the gross gamma count computing system and to the multichannel spectrum analyzer.

The gross gamma count system consists of an amplifierdiscriminator-computer package which counts and records the total number of gamma-rays of energy greater than $50 \mathrm{keV}$ that are detected during a precisely determined 1 -second time interval. The gross gamma count rate (number of detected gamma-rays per second) is measured every other second and is simultaneously and automatically recorded along with the aircraft position and altitude. Gross gamma count rates, typical of background, are several thousand per second.

As a backup and complement to the digital readout of the gross gamma count data, a record is made on a continuous strip chart plot of both gross gamma count rate and altitude as a function of distance.

Whereas the gross gamma count data specify the intensity of radiation as a function of position, the gamma spectral data identify the sources of radiation. A pulse height analyzer (PHA) automatically sorts detected gamma-rays according to energy, thereby generating a number-per-unit-energy versus energy spectrum. While nuclear gamma-rays occur only at well known discrete energies, characteristic of the emitting species, air scatter phenomena tend to smear the detected distribution. Nonetheless, the discrete characteristic peaks that permit isotopic identification are readily observable. A typical spectrum with identified species is shown in Fig. 1.1. In wide area surveys, the typical acquisition time for a gamma-ray spectrum is several minutes, thereby characterizing the average radiological properties of a tract several miles in length. However, if an area of interest is indicated by an increase of the gross gamma count data, spectral data acquisition times of only a few seconds are used to isolate the area spatially. If further investigation is warranted, a similarly 


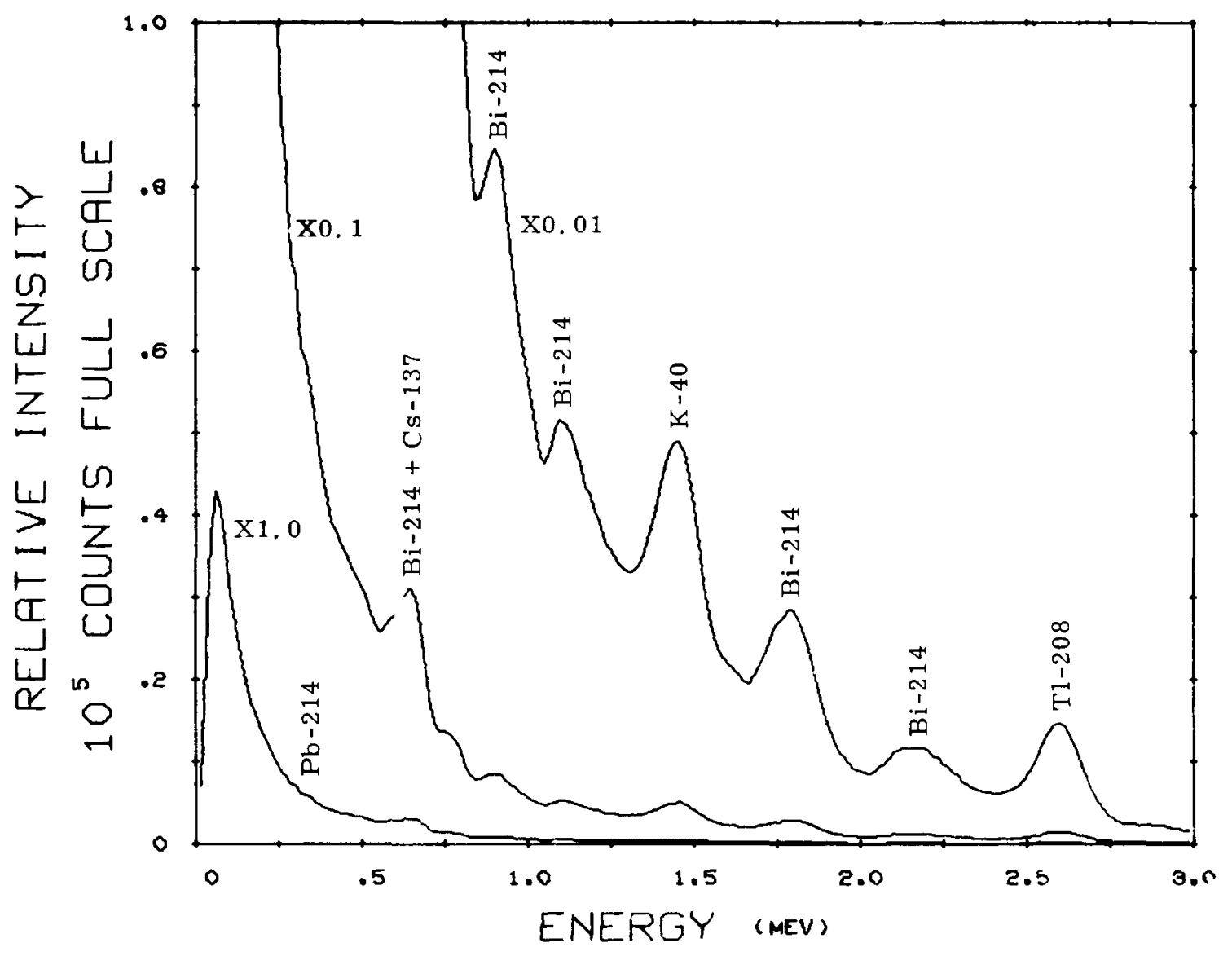

SPECTRUM NO. 249

DATE O8-12-69

LIVE TIME 4.00

INTEGRATED CT 。 538915

TYPE ACFT TERRAIN BKG。-GND. DEPO. ALTITUDE 300

AIRCRAFT (ARMS)

Figure 1.1 Typical ARMS $\gamma$-ray spectrum showing naturally occurring radionuclides. 
equipped ground mobile unit with greater areal and energy resolution is available as part of the ARMS program.

The equipment and procedures discussed, while sophisticated, offer great flexibility even during in-flight operation. Equipment may be tested and calibrated, detector sensitivities may be easily modified to accommodate large dynamic ranges of gamma radiation intensity, local areas of interest may be repeatedly scanned from different directions to get a detailed areal radiological profile, and the techniques can be applied equally well to the detection and identification of both diffusely dispersed or highly localized quantities of radioactive materials. Lastly, there exist no terrestrial or aquatic survey techniques capable of monitoring such large areas in such short times.

\section{4 REDUCTION AND PRESENTATION OF DATA}

The raw data from the gross gamma count and the gamma spectral measurements are permanently recorded on paper tape, and they must undergo reduction and analysis to characterize the radiological properties of the surveyed area.

Calibration measurements, which give the altitude dependence of the gross gamma count rate over a field of uniformly dispersed radioactivity, are utilized to convert the raw gross gamma count rate data (cps) plus the recorded altitude information to the biologically more significant exposure rate $(\mu \mathrm{R} / \mathrm{hr})$ at 3 feet above-ground, which is referred to here as "ground exposure rate." When 14 gamma-ray detectors are used at an altitude of 300 feet, 460 corresponds to $1 \mu \mathrm{R} / \mathrm{hr}$.

This exposure rate conversion factor was obtained by repeated flights, from 200 to 1000 feet above terrain containing known distributions of natural isotopes. Average gross counts from repeated surveys indicate a precision of $2 \%$, or better, (assuming similar meteorological conditions). These conversion factors have proved valid over distributed fission product fields, with a variation of less than $25 \%$. In practice, variations of $2 \mu \mathrm{R} / \mathrm{hr}$ or greater can be reliably observed in repeated flights over the same area.

At an altitude of 300 feet, the field of view of the system is approximately $1 / 4$ mile wide for a mean energy of naturally occurring isotopes. 


\section{REFERENCE}

1. "Aerial Radiological Measuring Systems (ARMS) - Systems and Procedures Employed Through FY71, "AEC Report No.

ARMS-71.6, in preparation. 


\section{1 SURVEY AREA}

The planned survey area for the Oyster Creek Reactor consisted of 25 flight lines approximately 12 nautical miles long and spaced 1 nautical mile apart. The flight lines were oriented in an east-west direction. The gamma-ray spectral, gross-count, aircraft position, and meteorological information were collected along the flight lines.

Since ARMS could not fly in the restricted area over the Lakehurst Naval Air Station, five of the proposed flight lines had to be omitted. For this reason, only 20 flight lines were actually flown.

\subsection{SURVEY PREPLANNING}

Preplanning for the survey consisted of locating the reactor site on appropriate topographic maps used for visual navigation, and making a real-time analysis of local meteorological conditions.

Prior to all survey missions flown over each site by the ARMS aircraft, a test line was flown over a strip of terrain in the area whose radiation signature was determined by previous flights. This procedure ensures that the survey equipment operates as it did on previous flights. 


\section{CHAPTER 3 OYSTER CREEK REACTOR AND SITE CHARACTERISTICS}

\subsection{SITE AREA CHARACTERISTICS}

The Oyster Creek Nuclear Power Plant is located near Tom's River, New Jersey. Currently operating at the site is Oyster Creek, Unit 1 , a boiling water reactor with a capacity of $650 \mathrm{MW}(\mathrm{e})$, owned and operated by the Jersey Central Power \& Light Company. Table 3-1 presents a breakdown of the population of the region in terms of radial distance and direction from the reactor site. The terrain within the survey area is comprised mainly of marsh lands associated with the coast line. The vegetation cover in this area is a mixture of forest and agricultural crops. There are also several small rivers and lakes in the area. 
Table 3-1. Population distribution within the Oyster Creek Nuclear Power Plant area. (Preliminary Data 1970 Census) ${ }^{1}$

\begin{tabular}{|c|c|c|c|c|}
\hline \multirow[t]{2}{*}{ Town } & \multirow{2}{*}{$\begin{array}{c}\text { Direction From } \\
\text { Power Station }\end{array}$} & \multicolumn{3}{|c|}{$\frac{\text { Radial Distance From Station (miles) }}{0-5}$} \\
\hline & & \multicolumn{3}{|c|}{ Population } \\
\hline $\begin{array}{l}\text { Barnegat } \\
\text { Barnegat Pines } \\
\text { Beachwood } \\
\text { Forked River } \\
\text { Gilford Park } \\
\text { Harvey Cedars } \\
\text { Island Heights } \\
\text { Lavallette } \\
\text { Manahawkin } \\
\text { Mayetta } \\
\text { Ocean Gate } \\
\text { Seaside Heights } \\
\text { Seaside Park } \\
\text { Silverton } \\
\text { Surf City } \\
\text { Tom's River } \\
\text { Waretown } \\
\text { Warren Grove } \\
\text { West Creek } \\
\text { Whiting }\end{array}$ & $\begin{array}{l}\text { S } \\
N E \\
N \\
N E \\
N E \\
\text { SE } \\
N \\
N E \\
\text { S } \\
\text { SW } \\
\text { N } \\
\text { NE } \\
\text { NE } \\
\text { N } \\
\text { S } \\
\text { N } \\
\text { SE } \\
\text { SW } \\
\text { S } \\
\text { NW }\end{array}$ & $\begin{array}{r}900 \\
200 \\
1,422\end{array}$ & $\begin{array}{r}4,390 \\
314 \\
1,397 \\
1,278 \\
1,081 \\
1,432\end{array}$ & $\begin{array}{r}4,007 \\
1,509 \\
150 \\
1,248 \\
600 \\
1,129 \\
7,303 \\
\\
600 \\
308\end{array}$ \\
\hline Totals & & 3,022 & 9,942 & 16,854 \\
\hline
\end{tabular}

\section{REFERENCE}

1. 1970 Census of Population, Advance Report, PC (VI)-32,

U. S. Department of Commerce, Bureau of Census, December 1970. 


\section{CHAPTER 4 RADIOLOGICAL SURVEY}

\section{1 SURVEY MISSIONS}

The aerial survey to collect radiological data of the Oyster Creek Reactor area was conducted 12 August 1969. This survey required a total flying time of 5.3 hours, consisting of several missions. The base of operations for this survey was Rockford, Illinois.

Gross count and spectral data were simultaneously collected at an altitude of 300 feet. Spectral collections were accumulated over a 4-minute live-time during which the aircraft traveled approximately 12 miles; consequently, 1 spectrum per line was collected.

\subsection{GROSS-COUNT DATA}

The typical nonterrestrial background encountered during a survey consists of cosmic ray, aircraft and airborne radioactivity contributors. A terrestrial radiation level from natural radiation of $10 \mathrm{uR} / \mathrm{hr}$ (at $3 \mathrm{ft}$ ) produces $5500 \mathrm{cps}$ in the detector array at $300 \mathrm{feet}$. An additional $500 \mathrm{cps}$ is contributed by aircraft background and cosmic radiation. The contribution from airborne radioactivity (primarily from radon daughters) is variable and can be as high as $1500 \mathrm{cps}$. The gamma-ray gross-count data and aircraft position information collected on the flight lines are processed by the computer to make an overlay on U.S.G.S. topographical maps. After accounting for the nonterrestrial background contributors ${ }^{1}$, the resultant net count data are computer processed to give an exposure rate in microroentgens per hour $(\mathrm{R} / \mathrm{hr})$ at the 3 foot level above terrain. The various exposure rates are processed into an isoexposure contour map, which is superimposed upon a map of the area.

An isoexposure map for the Oyster Creek Nuclear Power Plant is included as Figure 4.1. A cosmic radiation contribution of 2 to $4 \mu \mathrm{R} / \mathrm{hr}$ is included in the data shown on the map.

\section{3 SPECTRAL DATA}

Prior to takeoff on the survey mission, the system was calibrated with a Y -88 source. Yttrium -88 has two prominent gammas: 0.898 and $1.836 \mathrm{MeV}$. The calibration source is used to set the gain 


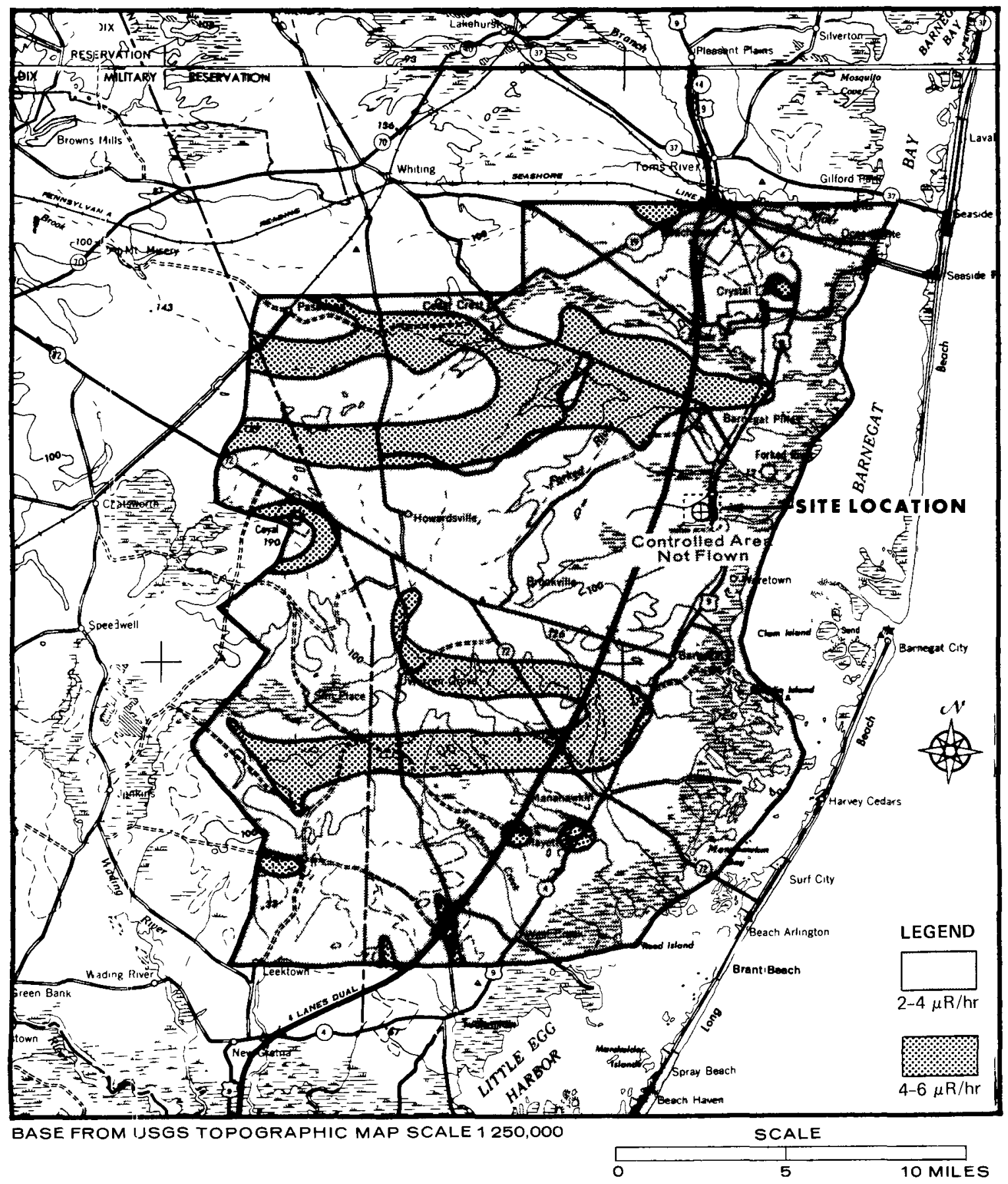

\section{GAMMARADIATION \\ EXPOSURE RATE CONTOURS \\ OYSTER CREEK. NUCLEAR POWER PLANT \\ NEW JERSEY AUGUST 1969}

Figure 4.1 
of each crystal of the 14-crystal array. Each gamma-ray detector is a $4 \times 4$ inch sodium iodide, thallium-activated, crystal. Spectral data are recorded from 0.0 to $3.0 \mathrm{MeV}$.

Spectra typical of the spectral data collected along the flight lines are included in Appendix A. The table preceding the spectral plots lists the energies and isotopes identified from the data. Only the more prominent photopeaks have been included in the tabulation A - 1. Only isotopes consistent with normal background radiation were observed in the spectral data. Included in the normal background is a detectable quantity of $\mathrm{Cs}-137$ from world-wide fallout.

\section{REFERENCE}

1. "Aerial Radiological Measuring Systems (ARMS) - Systems and Procedures Employed Through FY71, " AEC Report No. ARMS-71.6, in preparation. 


\section{1 REACTOR AREA}

The 240 square mile aerial survey of the Oyster C reek Nuclear Power Plant and surrounding area revealed that both the concentration and relative abundance of isotopes are consistent with normal background radiation throughout the United States. No apparent anomalies were detected that could be attributed to Oyster Creek Reactor operations.

\subsection{CONCLUSION}

The exposure rates mapped during the aerial radiation survey were predominantly in the 2 to $6 \mu \mathrm{R} / \mathrm{hr}$ range, 3 feet above the ground. 
This section contains typical spectral data from the crystal array that were taken along the flight lines flown over the Oyster Creek Reactor area.

The tabulation preceding the spectra shows the energies present in all the charts and the isotopic contributor associated with the photopeaks observed. 
Table A-1 Gamma-ray energies and isotopes consistent with spectral data collected along the flight lines.

\begin{tabular}{|c|c|c|c|}
\hline \multirow{2}{*}{$\begin{array}{l}\text { OBS. } \\
\text { ENERGY } \\
\text { (MEV) }\end{array}$} & \multicolumn{3}{|c|}{ RADIONUCLIDES CONSISTENT WITH SPECTRAL PHOTOPEAKS } \\
\hline & FISSION PRODUCTS & $\begin{array}{l}\text { ACTIVATION } \\
\text { PRODUCTS }\end{array}$ & BACKGROUNI) \\
\hline 0.35 & - & $-\ldots-1-1-n$ & $\mathrm{~Pb}-214$ \\
\hline 0.61 & $-\ldots . .$. & 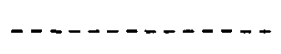 & $\mathrm{Bi}-214$ \\
\hline 0.66 & Cs -137 & 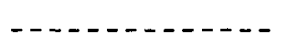 & $-\ldots$ \\
\hline 0.94 & 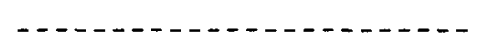 & $-\ldots-1-1-1-1$ & $\mathrm{Bi}-214$ \\
\hline 1.12 & 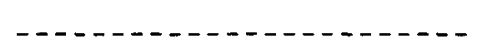 & $-\ldots-1-1-1-1$ & $\mathrm{Bi}-214$ \\
\hline 1.46 & 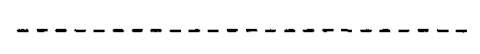 & 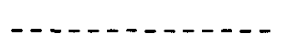 & $K-40$ \\
\hline 1.76 & - - & 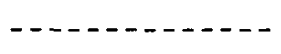 & $\mathrm{Bi}-214$ \\
\hline 2.20 & 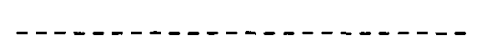 & $-\ldots-\ldots-1--1$ & $\mathrm{Bi}-214$ \\
\hline 2.62 & 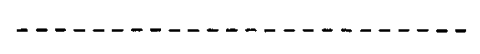 & $-\ldots \ldots-\ldots$ & $\mathrm{T} 1-208$ \\
\hline
\end{tabular}




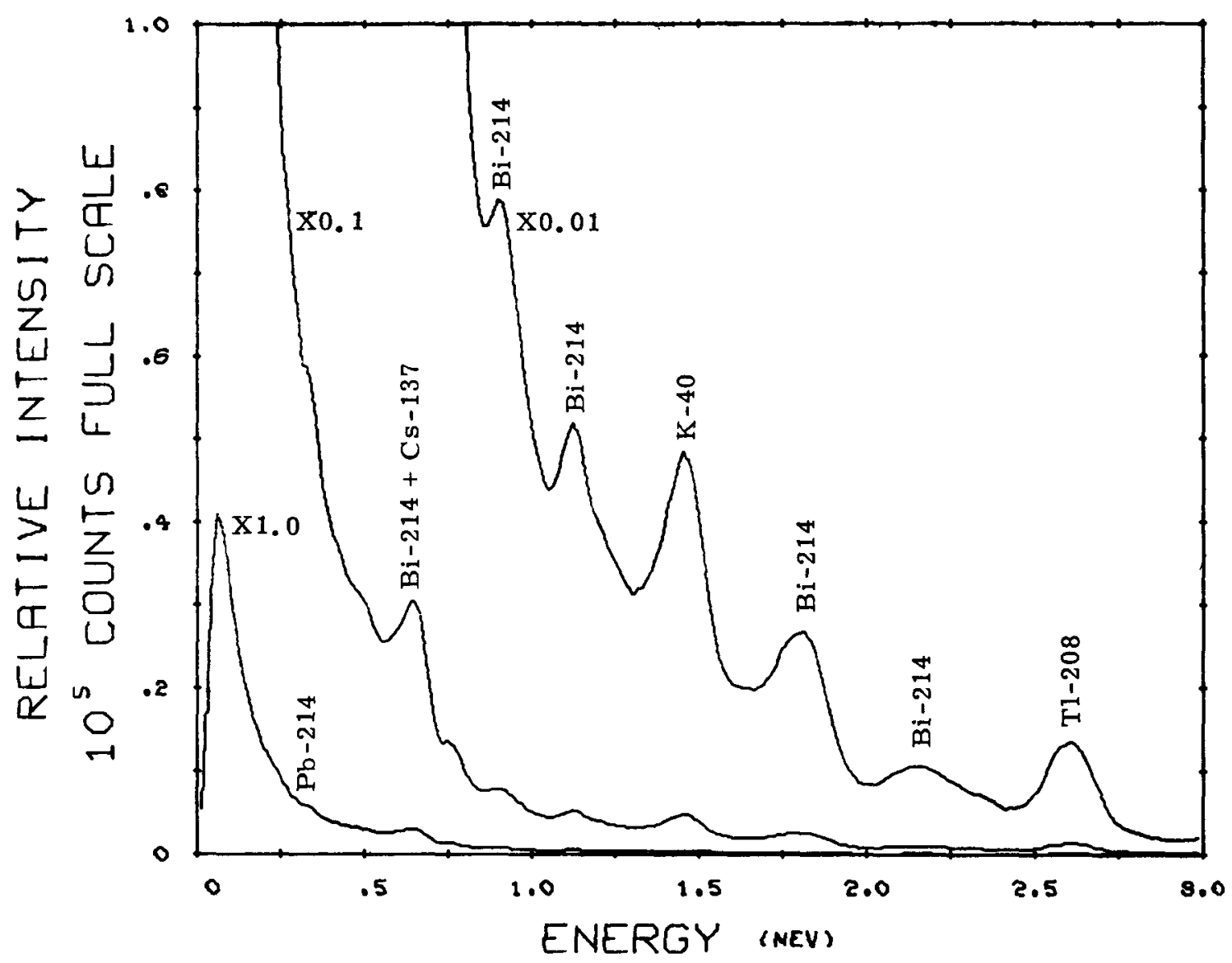

SPECTRUM NO. 250

CATE O8-12-69

LIVE TIME 4.00

INTEGRATED CT. 518955

TYPE ACFT TERRAIN BKG.-GND. DEPO.

RLT ITUDE 300

AIRCRAF T (RRMS) 


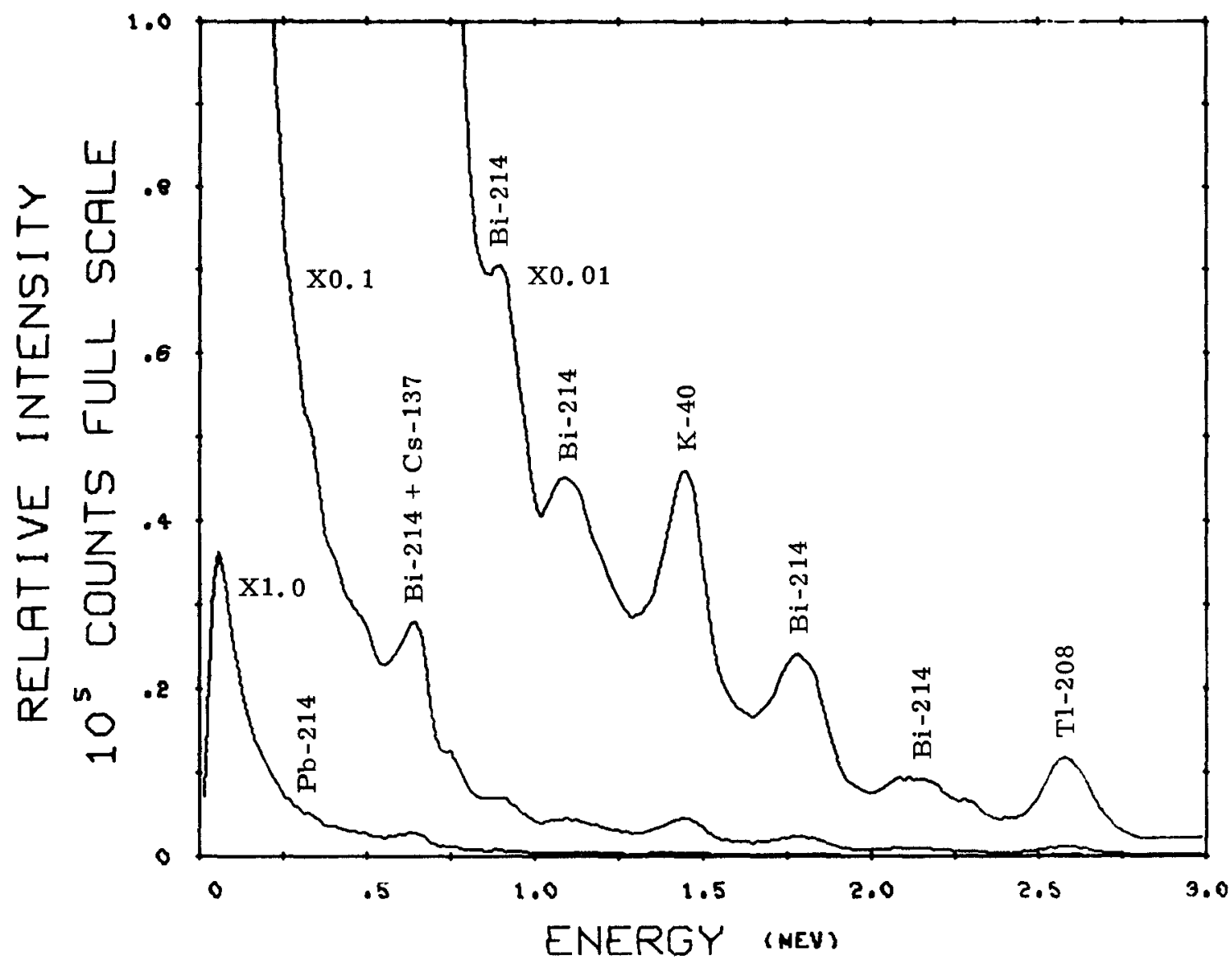

SPECTRUM NO. 256

DRTE OB-12-69

LIVE TIME $\quad 4.00$

INTEGRRTED CT. 460788

TYPE ACFT TERRAIN BKG.-GND. DEPO.

RLT ITUDE 300

AIRCRAF T (ARMS) 